\title{
Identifying the moral-practical gaps in corporate social responsibility missions of Vietnamese firms: an event-based analysis of sustainability feasibility
}

\author{
Vuong Quan-Hoang a , La Viet-Phuong a,b, Nguyen T. Hong-Kong ${ }^{\text {a,b }}$, Ho Manh-Tung ${ }^{\text {a,b }}$, Thu-Trang \\ Vuong ${ }^{c}$, Manh-Toan Ho ${ }^{\text {a,b,* }}$ \\ ${ }^{a}$ Centre for Interdisciplinary Social Research, Phenikaa University, Hanoi 100803, Vietnam; \\ ${ }^{\mathrm{b}}$ A.I. for Social Data Lab (AISDL), Vuong \& Associates, Dong Da district, Hanoi 100000, Vietnam; \\ ${ }^{c}$ Sciences Po Paris, 27 Rue Saint-Guillaume, 75007 Paris, France ; \\ *Corresponding author: Manh-Toan Ho (Email: toan.homanh@phenikaa-uni.edu.vn)
}

\begin{abstract}
This research was conducted in Vietnam in 2019 to support the establishment in 2018 of the Vietnam Business for Environment (VB4E) Platform by the International Union for Conservation of Nature (IUCN) Vietnam. The case of Vietnam is then used to bring attention to how businesses in a developing country are dealing with environmental problems and engaging in both ecological conservation and social responsibilities. A structured dataset on selected keywords and news sources was built to systematically track all major environment-related events in Vietnam. The findings, which were extracted from 344 news reports and 75 environmental events, highlight the lack of engagement on Vietnamese businesses in sustainability initiatives, with existing corporate activities still driven by practical concerns, i.e., profitability. Notably, a minimum of one governmental agency was involved in $86 \%$ of the events categorized as environmentally damaging. This result hints at a systemic problem of government-business collusion in bypassing environmental guidelines.
\end{abstract}

Keywords: corporate social responsibility missions; sustainability feasibility; Vietnamese firms; government-business collusion, socio-environmental sustainability.

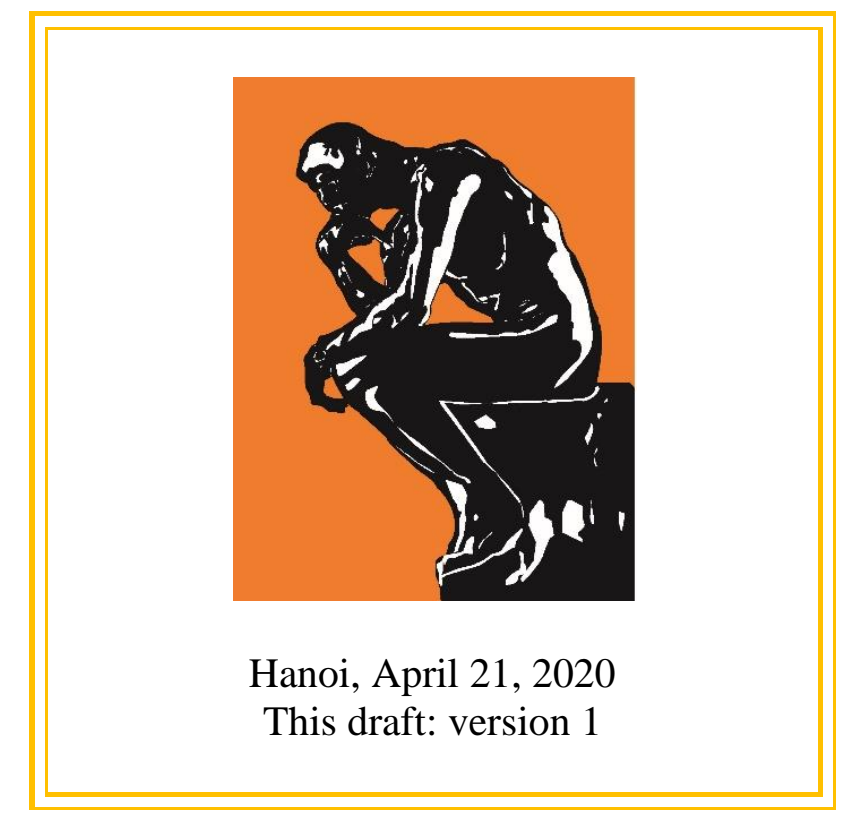




\section{Introduction}

Human well-being is a broad concept encompassing both physical and emotional health, work and recreation, supportive social relationships, and a satisfactory living environment. In many parts of the world, rapid urbanization and globalization have brought about unprecedented developments, enhancing such well-being for millions of people over the past decades. At the same time, the very forces that fuel the progress of modern societies worldwide, i.e., the industries and businesses, are generating glaring risks and problems to the environment, and in turn, jeopardizing human well-being at large. Given that sustainability problems, though regional or global in scale, often require local and individualized solutions, this paper proposes a detailed case study that exposes the double-edged sword of economic development but offers answers to the question at hand.

The focus is on Vietnam, particularly the sustainability challenges facing an economy and society that has grown from one of the world's poorest to a lower middle-income country in just three decades. On the one hand, economic indicators do show an impressive picture of poverty reduction. Between 2002 and 2018, the rate of poverty fell from over 70\% to below 6\% (USD3.2/day PPP), and the GDP per capita increased by 2.5-fold to hit USD2,500 (World Bank, 2020). On the other hand, there are costly prices for this rapid growth. From as early as the 1990s, deforestation and illegal logging have emerged as a major problem in Vietnam (FAO, 2001), and environmental pollution today continues to threaten human health (Anh et al., 2019; T. C. Hoang, Black, Knuteson, \& Roberts, 2019). It is clear that many parts of the population of 95 million have not enjoyed the fruits of the new-found wealth (McElwee, 2016; Meyfroidt \& Lambin, 2008; Q. H. Vuong, 2015).

In September 2015, Vietnam joined 192 other countries of the United Nations to adopt the 2030 Agenda for Sustainable Development - an ambitious universal declaration aimed at eliminating poverty, saving the planet from degradation, and fostering productive, vibrant and peaceful lives (United Nations, 2020). The historic move, however, hinges not just on the participation of every society member but also on an overhaul of the "business as usual" mindset, specifically in industry sectors and markets (Leisinger, 2015). As such, in examining the case of Vietnam, this paper pays attention to the local businesses and their responses to the global change, i.e., a growing emphasis on sustainability challenges and the ethical aspects of entrepreneurship. Given that the topic of business engagement in sustainability in Vietnam is still in its infancy, with much of the emphasis on business activities to reduce environmental degradation, the focus of the analysis is on the local businesses' awareness of socio-environmental risks and issues. This constitutes the first stage in the proposed three stages of engagement, as shown in Figure 1.

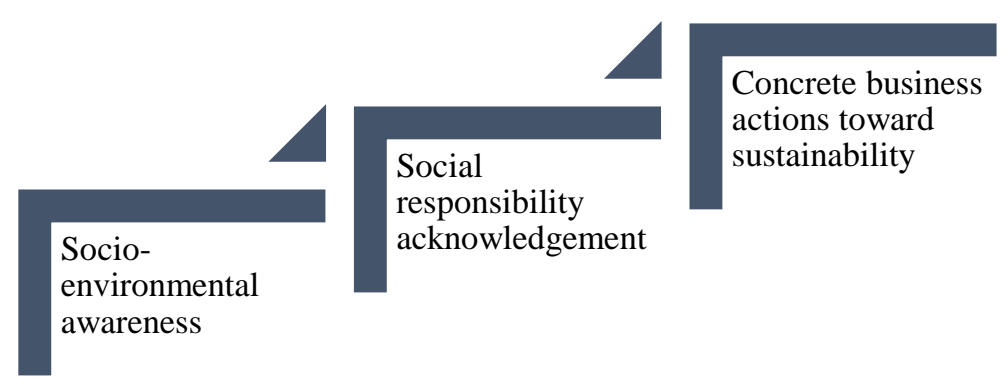

Figure 1. Three stages of business engagement in sustainability

The study, conducted in Vietnam in 2019 to support the establishment in December 2018 of the Vietnam Business for Environment (VB4E) Platform by the International Union for Conservation of Nature (IUCN) Vietnam, analyzes business participation in environmental initiatives in Vietnam. The 
goal is to provide insights into how much businesses in a developing economy grasp the scope of the problems and what steps they take to solve them, whether in an individual or collaborative manner.

\section{Literature Review}

\subsection{A moral dimension: from being aware to acknowledging responsibility}

Entrepreneurial activities are dealing with increasingly complicated questions not just concerning their functionality or profitability, but also the sustainability of their own operations and the environment at large. Questions on sustainability arguably pertain to the domain of business ethics, for they ask entrepreneurs to bridge the gaps between "what they usually do" and "what they should do" (Morris, Schindehutte, Walton, \& Allen, 2002; Vallaster, Kraus, Merigó Lindahl, \& Nielsen, 2019). Business organizations have to reflect on the moral responsibility toward the environmental and social impact of their actions. There are hundreds of academic concepts and definitions to describe a more humane and transparent way of doing business (van Marrewijk, 2003), with some notable ideas being social responsibility (Davis, 1973), the normative strand of stakeholder theory (Donaldson, 1982), the "Triple Bottom Line" or "People, Planet, Profit" (Elkington, 1994), or the new corporate citizenship of big business (Marsden, 2000). Other more prominent terms in the literature appear to be corporate sustainability, corporate social responsibility (CSR), and social entrepreneurship, with the earliest studies traced back to the 1950s (De Bakker, Groenewegen, \& Den Hond, 2005; Vallaster et al., 2019).

The term corporate sustainability deals with sustainability measures at the corporate level, and thus, encompasses all elements such as CSR and corporate responsibility-whether it be economic, environmental, or social (Panapanaan, Linnanen, Karvonen, \& Phan, 2003; van Marrewijk, 2003). CSR is considerably the most developed concept during the twentieth century but has not gone uncontested with regard to its definitions and compositions (Moratis, 2016). The term CSR encompasses several dimensions but is always rooted in the normative idea of a company's responsibilities for its impacts (Moratis, 2016). The lack of consensus on its definition is attributable to the fact that research approaches to CSR for many years have been narrowed to the corporate duties, and thus, separated from other research concerned with ethics (De Bakker et al., 2005; Vallaster et al., 2019). While the recent literature has witnessed a re-focus on CSR and entrepreneurship at both large and small organizational scales (Hammann, Habisch, \& Pechlaner, 2009; Hemingway, 2005), there seems to be disagreement still on the types of behavior and action that are deemed socially responsible in society. This has led to the emergence of two dominant viewpoints among researchers: one looking at the contradictions between ethical behavior and economic success (Gray, 2010; Milne \& Gray, 2013), and the other at the effects of sustainability management on corporate profitability and competitiveness (Carroll \& Shabana, 2010; Schaltegger \& Synnestvedt, 2002; Wagner, 2010).

What can be noted in the moral dimension is that business engagement in sustainability requires, first and foremost, an understanding of the business' impacts on the surrounding society and environment. Second, the process from being aware of a business' role to acknowledging its responsibility may either create contradictions within itself or turn out to facilitate its growth.

\subsection{A practical dimension: from acknowledging to acting}

In moving toward the business' adoption of concrete actions on sustainability, one needs to look at the drivers of such initiatives. This aspect is best understood when looking at the growing interest in the umbrella term "corporate sustainability" for it is an approach many businesses are adopting not only to distinguish themselves from competitors but also to reduce costs (e.g., energy-saving, cleaner production) and take on risks (Folmer \& Tietenberg, 2005). The ethical motivations of businesses to CSR, according to Schaltegger and Burritt (2018), can be summarized in four types, namely (i) reactionary concern for short-term financial interests, (ii) reputational concern, (iii) genuine concern for improving social and 
environmental performance, and (iv) collaborative matter for facilitating social relations and participation beyond the firm. Depending on the motivation, a business would see a different outcome in the effects of its socio-environmental activities on economic performance. Here, the authors point out the overwhelming advantage of the fourth motivation - which is to facilitate collaborative dialogue and empathy-based management with vulnerable stakeholders - such that it helps reduce costs all the while increasing business reputation, sales, radical innovations, employee attractiveness, and business model innovation (Schaltegger \& Burritt, 2018). This line of analysis relies on two fundamental elements, namely the costs involved in the CSR activities and their outcomes, which are measured in the social, environmental, or economic benefits. More importantly, none of the ethical motivations are mutually exclusive for the business movement toward sustainability is dynamic.

While there is a growing acceptance of the corporate sustainability framework as one that integrates economic, environmental, and social dimensions, within the discourse on actionable sustainability initiatives, environmental risks appear to have taken up considerable room. Two reasons could account for this. First, citizens, businesses, and governments across continents have gained an acute awareness about the severity of environmental degradations and the irreversibility of many actions (Leisinger, 2015). Second, developments on the conceptual front have cemented the foundation for capturing and analyzing these risks, e.g., the introduction of ecologically sustainable development by World Commission on Environment and Development (1987) and the broad international recognition of the "precautionary principle" in the Rio Declaration on Environment and Development (United Nations, 1992). Achieving corporate sustainability in the environmental dimension may not guarantee simultaneous success in the other two due to trade-offs and conflicts (Hahn, Figge, Pinkse, \& Preuss, 2010). Yet, it is crucial to understand the weight of each aspect and to contextualize its contributions to sustainability as a whole.

\subsection{Sustainability practices: a divided world}

Beyond the theories, what are the actual motivations and approaches to corporate sustainability around the world? Exploratory studies have shown that this discourse is concentrated in developed countries where sustainability issues are increasingly institutionalized (Bansal \& Bogner, 2002; Bansal \& Roth, 2000). For instance, the motivations for investing in a social agenda-whether they be about sustainability, legitimacy, and profitability—among Norwegian companies vary across different industries, with businesses in the oil industry largely driven by reputation and legitimacy motives while those in tourism more concerned about society's future (Brønn \& Vidaver-Cohen, 2009). Meanwhile, business respondents in the United Kingdom and Japan are found to be motivated by competitiveness, legitimation, and ecological responsibility, which are influenced by contextual conditions (Bansal \& Roth, 2000). The concern for organizational legitimacy is also witnessed in Swedish companies that use corporate sustainability reporting (Hedberg \& von Malmborg, 2003). By comparison, a survey of companies in Germany shows that the majority has not only adopted a proactive approach but also acted as innovators on socio-environmental issues. Yet, only a small fraction has incentivized employees to pursue sustainable behavior (Hahn \& Scheermesser, 2006). In terms of approach, the German firms frequently use ecological procurement guidelines and environmental reporting but do not implement social management tools or social reporting on the same scale (Hahn \& Scheermesser, 2006). Overall, from a global comparative perspective, corporate sustainability approaches are confirmed to be vastly different by regions, with the United States shown to be lagging behind both the European Union and the Asia Pacific in sustainability leadership (Moore \& Jie Wen, 2008).

While terms such as corporate sustainability and CSR have gained traction in developing countries in the past decade, research on the topic remains generally fragmented (Jamali, 2014). To explain the divide in implementing corporate sustainability measures including CSR between the Global 
North (the developed) and South (the developing), scholars have often pointed to the Western origin of these sustainability concepts and their inherent incompatibility with corporate environment and society in other parts of the world (Gugler \& Shi, 2009; Jamali, 2014; Khan \& Lund-Thomsen, 2011). The focus tends to be on CSR alone rather than the encompassing notion of corporate sustainability. In this sense, CSR activities in developing countries are frequently characterized as informal, localized, ongoing, more philanthropic, and even involving cultural/religious values (Amaeshi, Adi, Ogbechie, \& Amao, 2006; Jamali, 2014; Visser, 2008). Specific studies that employ the conventional CSR framework and vocabulary, meanwhile, do highlight the strategic or profit motive among the key drivers for businesses to pursue sustainability measures, as evidenced in India (Arevalo Jorge \& Aravind, 2011), China (Zhu \& Zhang, 2015), and Africa (Idemudia, 2011). As such, sustainability actions taken by the business and industry sectors often take the form of donation and philanthropy, which some scholars have noted as the initial step of acknowledging and committing to being socially responsible without necessarily making changes to the business conduct (Idemudia, 2011; Zadek, 2001).

\subsection{Where Vietnam stands}

Against this background, the research landscape on business engagement in sustainability in Vietnam can be characterized as sporadic and underdeveloped. There is insufficient engagement in the critical literature on corporate sustainability, and the concept of CSR, which was first introduced by international corporations sometime in the 2000s, remains vague and its adoption limited (Hamm, 2012; M. Nguyen \& Truong, 2016; Tencati, Russo, \& Quaglia, 2010). This could be due to the long-dominant assumption that businesses are profit-driven, and thus, are not represented as agents of sustainable development. Additionally, as Vietnam is portrayed as an emerging player in the global supply chain, sustainability studies in this context have reflected the trend in the developing world, such that they tend to be informal, pragmatic, and philanthropic in nature (Hamm, 2012). Given the aim of this study is to identify business engagement in environmental initiatives rather than the whole umbrella term of "CSR," the focus is narrowed to the environmental dimension of corporate sustainability. The two other social and economic dimensions are discussed alongside as businesses do not make decisions based on a single element.

Within the literature on environmental sustainability at the corporate level in Vietnam, the tourism/travel industry is seen as the most proactive promoter and actor. Yet, a closer look reveals that this phenomenon is quite recent. While the concept of "sustainable tourism" has attracted scholarly interest from as early as the 1980s (Liu, 2003), the idea was considered relatively new and even risky within Vietnam's tourism industry in 2005, according to a survey of 149 local tour companies and nearly 500 hotels (Le, Hollenhorst, \& Triplett, 2005). The concept has taken over a decade to catch on, understandably because of the rapid growth of the industry and the mounting environmental pressure placed on tourist destinations nationwide (Tseng et al., 2018). Sustainable tourism efforts now include building community-based ecotourism (Khanal \& Babar, 2007), changing past system behavior in tourism planning (Mai \& Smith, 2015), adopting green human resource practices (Luu, 2018), increasing environmental collaboration, knowledge sharing, and incentive alignment (Tseng et al., 2018).

By contrast, manufacturing and heavy-industry companies have yet to fully bridge the moral and practical dimensions of environmental sustainability, if not to say many companies in the energy and environmentally-sensitive sectors remain apathetic to climate change issues and lack response strategies (D. B. Hoang \& Do, 2016; Q. A. Nguyen \& Hens, 2015). When broken down by firm type, multinational enterprises are shown to be more engaged than domestic enterprises in tackling environmental problems (Hamm, 2012; D. B. Hoang \& Do, 2016). This includes companies in fields suffering direct adverse effects of pollution, such as the livestock industry (Nam, 2016). 
Besides sustainable tourism, a number of green concepts have taken off in other sectors, including green product innovation (Lin, Tan, \& Geng, 2013), green supply chain management (GSCM) in food and coffee production (Khoi, Dung, \& Nga, 2016; G. N. T. Nguyen \& Sarker, 2018), green bank and green credit (Do \& Tran, 2017; Tu \& Yen, 2015), green building (H. T. Nguyen \& Gray, 2016), and EcoIndustrial Park (EIP) (Stucki et al., 2019), among others. Scholars generally confirm that the adoption of green strategies, such as GSCM and green bank, has resulted in improving public image, saving cost, reducing waste and emission, gaining tax incentives and marketing advantage (Khoi et al., 2016; G. N. T. Nguyen \& Sarker, 2018; H. P. Nguyen \& Pham, 2011; T. T. H. Nguyen, Yang, Nguyen, Johnson, \& Cao, 2019; Tu \& Yen, 2015). These findings highlight the practical nature of such strategies. The upside is, there is a growing body of research on Vietnamese businesses' engagement in environmental sustainability, and the literature does an acute awareness of the importance of going green, regardless of the underlying economic incentives.

Yet, what remains missing in the scholarship is empirical evidence across different sectors concerning the specific business and environmental initiatives in Vietnam. Which companies or industries are the leading actors and polluters? Who are the stakeholders? What are the implications of these actions and potential lessons for Vietnam moving forward as well as other developing countries? These are some of the questions driving the rationale of this research.

\section{Materials and Methods}

The research was conducted in Vietnam in 2019 to support the establishment in December 2018 of the Vietnam Business for Environment (VB4E) Platform by the International Union for Conservation of Nature (IUCN) Vietnam. The VB4E initiative, based on the Biodiversity Sri Lanka (https://biodiversitysrilanka.org/) with modifications to fit the context in Vietnam, sets out to engage local enterprises in environment and biodiversity conservation issues through cooperative projects in six primary areas: plastic waste management, marine and coastal conservation, water and wetland conservation, sustainable tourism development, biodiversity, forest landscape restoration. This in-depth analysis of business participation in environmental initiatives in Vietnam improves the current understanding of corporate sustainability from both the moral and practical dimensions as well as facilitates the formulation of strategic plans for VB4E.

To build a structured dataset on the topic of concern, the study deploys a customized web crawling tool to scan the news and data sources about the possible relations between environment and businesses in Vietnamese news outlets and official government websites. A list of keywords was created in order to filter the news data, collecting only news reports that are relevant to the topics. The keywords are provided in Table 1.

Table 1. Vietnamese keywords, with translation in the bracket, for the web crawling tool to scan the news data

\begin{tabular}{|c|c|c|}
\hline Business & Environment & Solution \\
\hline Doanh nghiẹp [enterprise] & $\begin{array}{l}\text { ra môi truòng [discharged } \\
\text { into the environment] }\end{array}$ & $\begin{array}{l}\text { trồng cây xanh } \\
\text { planting] }\end{array}$ \\
\hline Công ty [company] & chất thải [waste] & xủ lý rác [waste processing] \\
\hline Tập đoàn [corporation] & xả rác [throwing trash] & $\begin{array}{l}\text { xü ly nuoóc [wastewater } \\
\text { treatment] }\end{array}$ \\
\hline $\begin{array}{l}\text { Nhãn xanh Việt Nam } \\
\text { [Vietnam }\end{array}$ & xả thải [discharging waste] & $\begin{array}{l}\text { bảo vệ môi truòng } \\
\text { [environmental protection] }\end{array}$ \\
\hline nhà máy [factory] & ô nhiễm [pollution/polluted] & bảo vệ nguồn nước [water \\
\hline
\end{tabular}




\begin{tabular}{|c|c|c|}
\hline & & protection] \\
\hline Formosa & nuóc thải [discharged water] & $\begin{array}{l}\text { xủ ly chất thải [waste } \\
\text { treatment] }\end{array}$ \\
\hline Zero Waste Saigon & rác thải [garbage] & $\begin{array}{lcc}\text { bảo về } & \text { rùng } & \text { [forest } \\
\text { protection] }\end{array}$ \\
\hline ngân hàng xanh [green bank] & $\begin{array}{l}\text { sư cố môi truòng } \\
\text { [environmental incident] }\end{array}$ & tái chế [recycling] \\
\hline \multirow[t]{10}{*}{ Hơp tác xã [cooperatives] } & rác thải nhụa [plastic waste] & $\begin{array}{l}\text { kiểm soát ô nhiếm [pollution } \\
\text { control] }\end{array}$ \\
\hline & tràn dầu [oil spill] & $\begin{array}{l}\text { phân loại rác [trash } \\
\text { categorization] }\end{array}$ \\
\hline & phá rùng [deforestation] & $\begin{array}{l}\text { năng lương xanh [green } \\
\text { energy] }\end{array}$ \\
\hline & $\begin{array}{l}\text { khai thác cát trái phép } \\
\text { [illegal sand mining] }\end{array}$ & $\begin{array}{l}\text { phát triển bền vũng } \\
\text { [sustainable development] }\end{array}$ \\
\hline & $\begin{array}{l}\text { môi truờng sinh thái } \\
\text { [ecosystem] }\end{array}$ & thu gom rác [trast collection] \\
\hline & $\begin{array}{l}\text { tàn phá môi truờng } \\
\text { [environmental damage] }\end{array}$ & $\begin{array}{l}\text { cắt giảm rác thải [garbage } \\
\text { reduction] }\end{array}$ \\
\hline & $\begin{array}{l}\text { hủy diẹt môi truoòng } \\
\text { [environmental destruction] }\end{array}$ & $\begin{array}{l}\text { giảm nguyên liệu tiêu thu } \\
\text { [input material reduction] }\end{array}$ \\
\hline & $\begin{array}{l}\text { nhiễm bẩn nguồn nước } \\
\text { [contaminated } \\
\text { sources] }\end{array}$ & $\begin{array}{l}\text { bảo tồn đa dạng sinh hoc } \\
\text { [biodiversity conservation] }\end{array}$ \\
\hline & $\begin{array}{l}\text { thải khi nhà kinh [greenhouse } \\
\text { gas] }\end{array}$ & $\begin{array}{lcc}\text { đổi mó́i } & \text { xanh } & \text { [green } \\
\text { innovation] }\end{array}$ \\
\hline & $\begin{array}{l}\text { biến dổi khi hậu [climate } \\
\text { change] }\end{array}$ & \\
\hline
\end{tabular}

As Table 1 shows, there are three main categories of concern: Business, Environment, and Solution. The Business category consists of keywords that are related to business and firms. The Environment category is comprised of keywords that describe environmental issues or harmful actions to the environment. Finally, the Solution category collects keywords that demonstrate pro-environmental actions and behaviors. The term "CSR" was intentionally left out of the search because it is a catch-all term that could cover non-environmental-related activities such as increasing support for employee welfare or community welfare (Hamm, 2012).

Based on the keywords, the web crawling tool scanned and collected the news data from as far as the newspapers' databases allow. In Vietnam, newspapers only store their data for a three- to five-year span; especially, prominent newspapers such as Tuổi Trẻ (Youth) or Thanh Niên (Young People) only allows a backtrack of 100 pages of contents, regardless of the date. The raw data were manually cleaned, then categorized based on its characteristics and participants, after which a comprehensive dataset was set up in the SQL database for further analysis.

The database contains four main groups:

- Group of news crawling settings

- Group of collected news

- Group of environmental events (Damaging the environment, Protecting or improving the environment, Others) 
- Group of participants in the environmental events (Business, Government agency, International organization, Others).

In Table 2, sources of news are summarized as follows:

Table 2. Sources of news

\begin{tabular}{llll}
\hline$\#$ & Source & $\begin{array}{l}\text { Number of retrieved } \\
\text { news stories }\end{array}$ & $\begin{array}{l}\text { Number of stories } \\
\text { after cleaning }\end{array}$ \\
\hline $\mathbf{1}$ & $\begin{array}{l}\text { Tuổi Trẻ } \\
\text { tuoitre.vn }\end{array}$ & 510 & 162 \\
\hline $\mathbf{2}$ & $\begin{array}{l}\text { Thanh Niên } \\
\text { thanhnien.vn }\end{array}$ & 52 & 3 \\
\hline $\mathbf{3}$ & $\begin{array}{l}\text { Department of Water Resources } \\
\text { Management } \\
\text { dwrm.gov.vn }\end{array}$ & 24 & 2 \\
\hline $\mathbf{4}$ & $\begin{array}{l}\text { Hanoi Department of Natural } \\
\text { Resources and Environment } \\
\text { www.tnmtnd.hanoi.gov.vn }\end{array}$ & 11 \\
\hline $\mathbf{5}$ & $\begin{array}{l}\text { Ho Chi Minh City Department of } \\
\text { Natural Resources and Environment } \\
\text { www.donre.hochiminhcity.gov.vn }\end{array}$ & $\begin{array}{l}\text { Tiề Phong } \\
\text { tienphong.vn }\end{array}$ & 145 \\
\hline $\mathbf{6}$ & $\begin{array}{l}\text { Quang Nam Province Department of } \\
\text { Natural Resources and Environment }\end{array}$ & 1 \\
\hline
\end{tabular}

The process of data collection and analysis is presented in Figure 2. All tools and datasets are maintained for future mining. The dataset is expected to grow over time, offering new opportunities for further analysis for deeper (and more useful) insights.

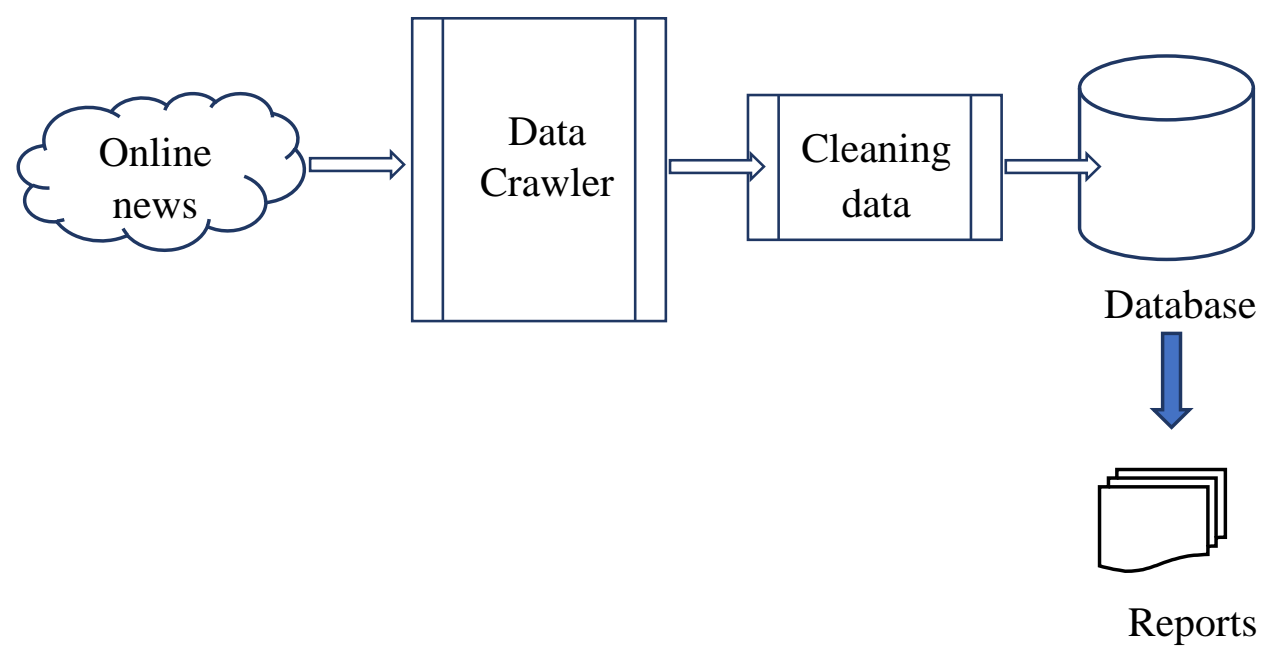

Figure 2. The process of data collection and analysis 
Next, in Figure 3, the structure of data in the above-mentioned SQL database is illustrated. Basically, the figure represents a system of related data tables that can be connected through some data properties. These properties can later be used to perform "query" that can yield useful insights into the information and news stored in the system.

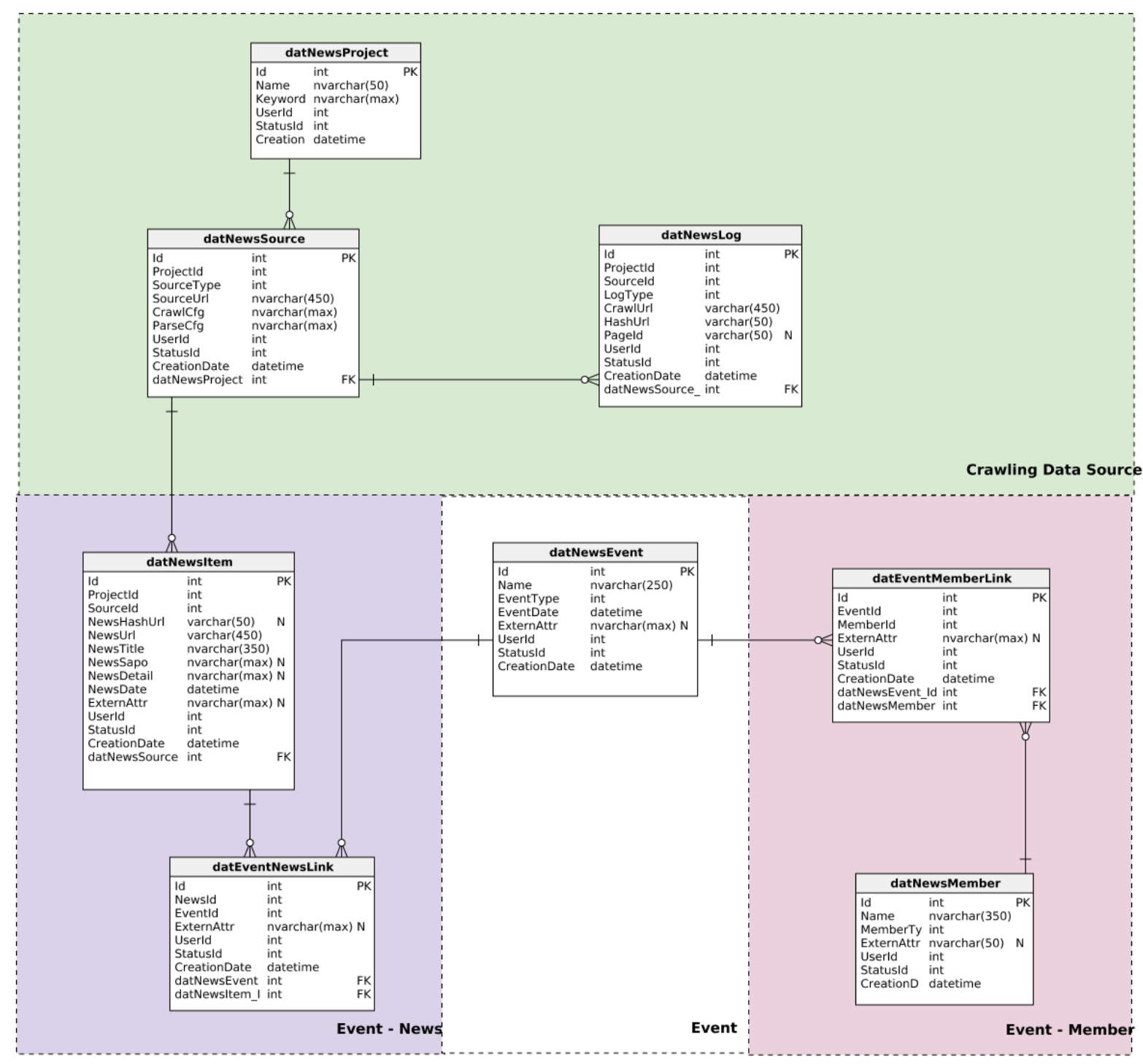

Figure 3. The structure of data

\section{Results}

From seven sources (see Table 2), we have retrieved 955 news reports, and the number was finalized at 344 news reports after the data was cleaned manually. Sourcing from 344 news reports, 75 environmental events were found, which include:

- 52 events about damaging the environment (Type of event $=1)$

- 20 events about protecting and improving the environment (Type of event $=2$ )

- Four other environmental events (Type of event $=3$ ) 


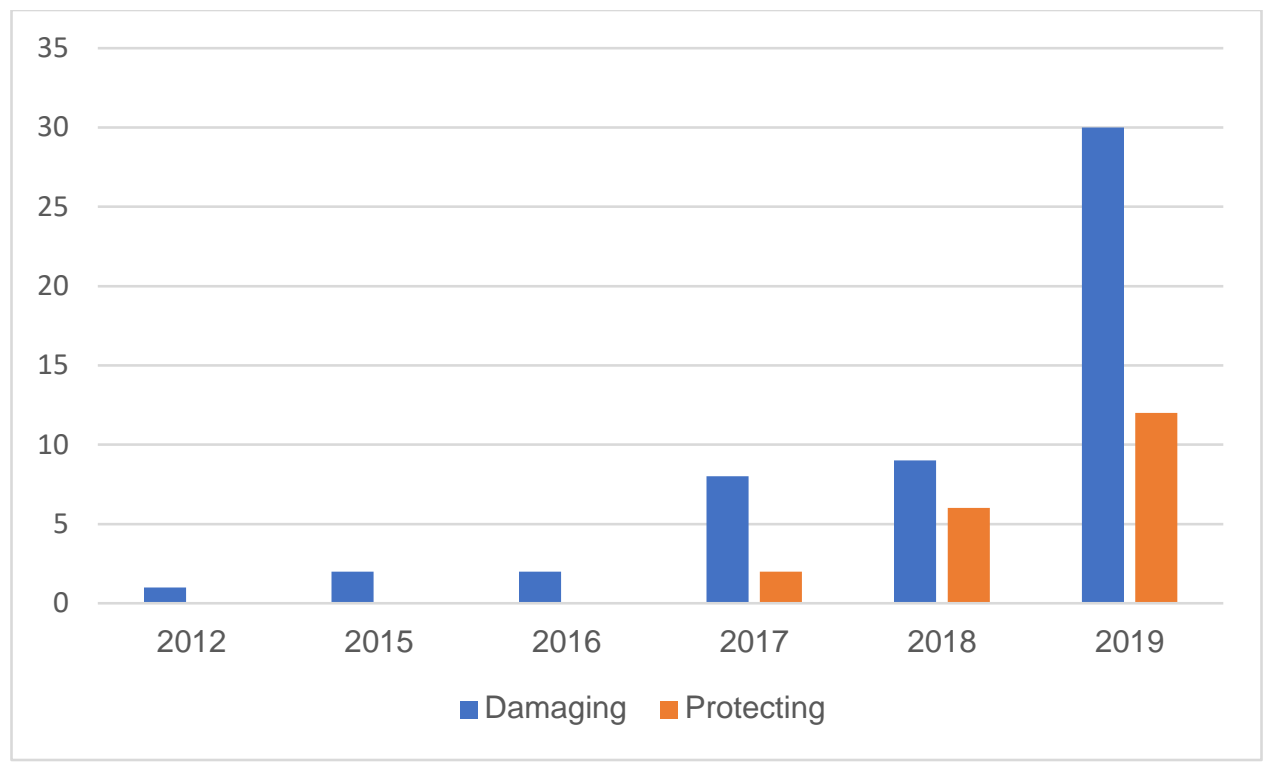

Figure 4. Number of damaging/protecting environment event by year

All of the 52 environment-damaging events involved businesses. And at least one government agency played a role in 45 out of 52 events. Notably, there is no event with the presence of international organizations. A majority of the environmental damages were caused by manufacturing industry businesses, followed by logistics and forestry businesses (see Figure 4).

It is also noteworthy that $11 \%$ of the violating businesses belong to the environment industry, even though they are supposed to take the responsibility of protecting the environment and conducting waste treatment. The incidents were reported to happen near their factories (Thanh, 2017), or during the waste treatment processes (Truong, 2017). This finding agrees with Binh and Khang (2016), which suggests that energy and sensitive environmental sectors in Vietnam are not responsive to environmental issues, and the response strategy is also limited. Lockrey et at. (2016) pointed out the risk of the existing recycling system being overloaded and cannot keep up with the pace of urbanization in Vietnam. 


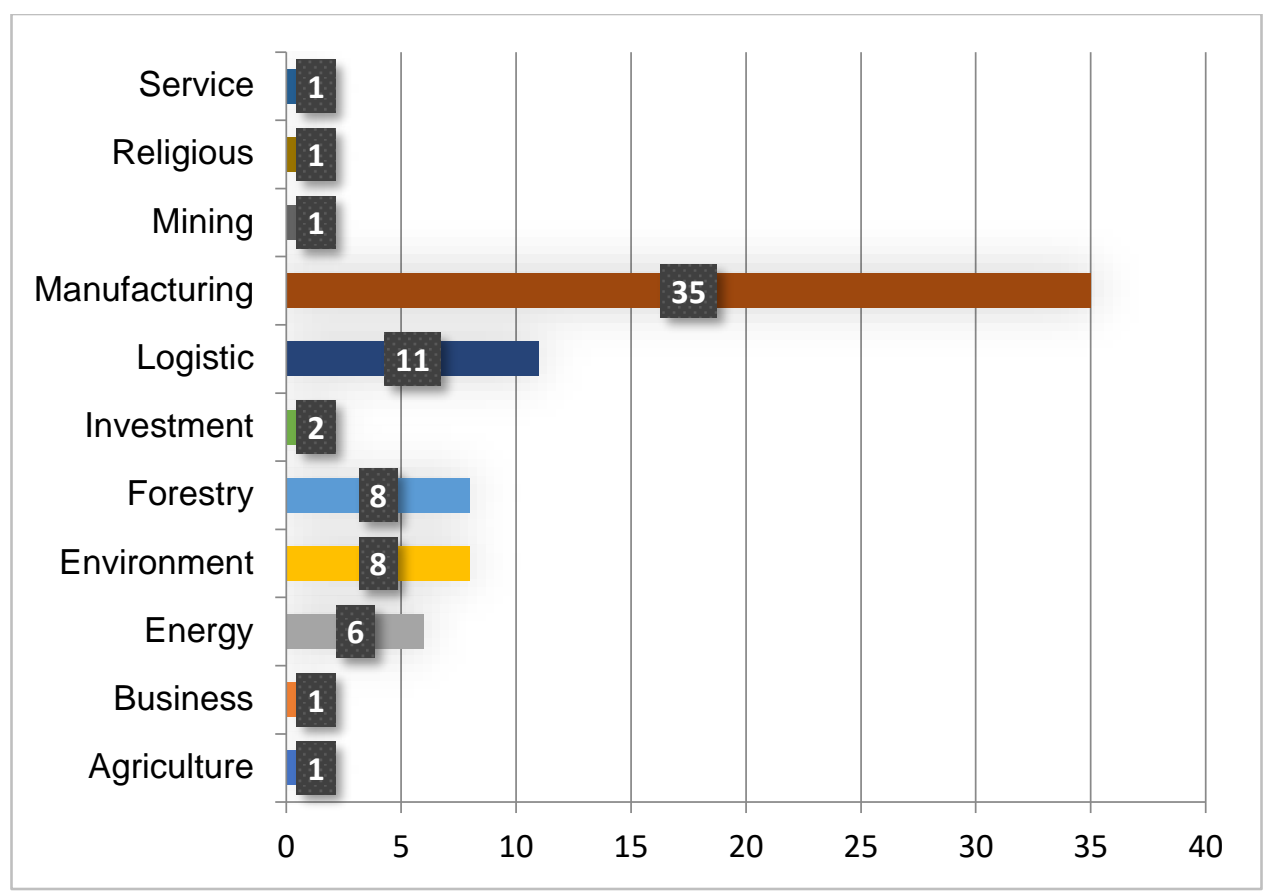

Figure 5. Violators of environmental regulations by industry

Of the 20 events that generated positive impacts on protecting and improving the environment, 17 events involved businesses, while information was unclear in the three remaining events. For instance, the event “Thoải mái nhu ở nhà - Comfortable as at one's home" encouraged hotels, restaurants, stores in Ba Ria Vung Tau province to use their restrooms as public restrooms for tourists (Ha, 2019), but the names of participants were not clarified. In 15 events, government agencies participated as the organizer (Hoa, 2017), or the supporter (Anh, 2019). Meanwhile, international organizations participated in only four events. Domestic environmental NGO/NPOs, which are also an important stakeholder in promoting proenvironmental behaviors, include the Center of Hands-on Actions and Networking for Growth and Environment (CHANGE), Keep Vietnam Clean and Green, Save Your Ocean, Vietnam Recycles (VNTC). They have organized cleaning or recycling garbage events and educating and training staff of business in pro-environmental behaviors. 


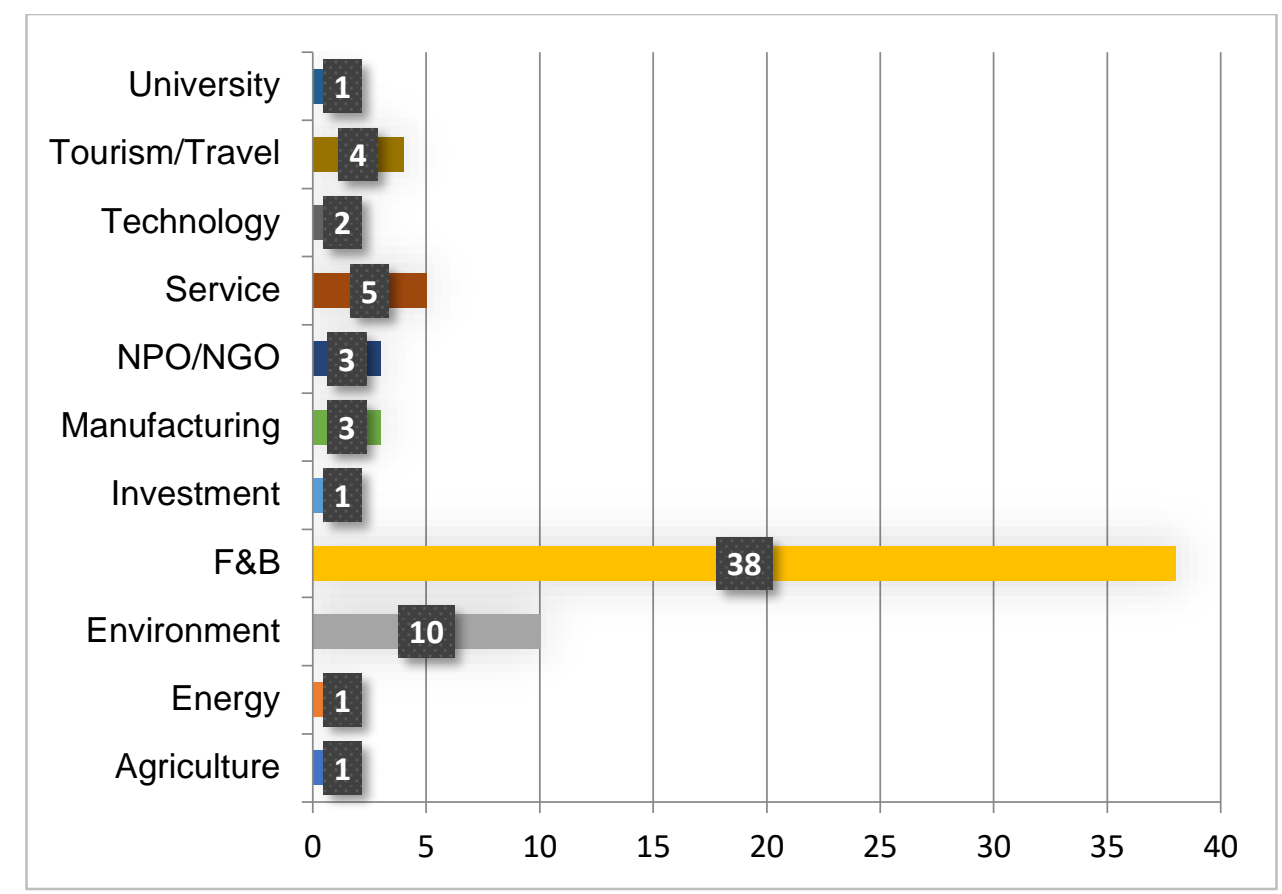

Figure 6. Contributors to environment protection and improvement events by industry

The events aimed to clean the environment by reducing plastic, sorting, and disposing of garbage. Food and beverage, service, and tourism industries are the most active in these events, especially coffee shops such as Cùi Dìa café, Starbucks, Là Việt Coffee, or restaurants like Boulevard Grill (see Figure 65). However, there are two pretentious initiatives in the cases of Phúc Long Coffee and Tea, and Highlands Coffee. Details of the participants' industry can be seen in Figure 4. In the case of Phúc Long, the coffee chains provided a garbage bin with sorting function, but it turned out to be fake; meanwhile, Highlands called for the abortion of plastic, but plastic cups and spoons are still being used in Highlands' stores.

The involvement of a government agency is also notable (Figure 6). Each level of a government agency has a similar proportion in dealing with damaging environment events, the ministry level is $36 \%$ of the events, province/city level $38 \%$, and district level 26\%. The proportion suggests much effort is being put into fixing the environmental damage. The ministry-level agencies have to involve in damaging events (36\% of the events) more than protecting ones (16\%). A majority of protecting environment events welcomed the presence of province/city level agencies (67\%), thus, implying there are more events at this level. Finally, it should be stressed that district-level agencies had low figures in both types of events.

One can notice that the involvement of the district-level government agency plays a crucial role because their personnel is closer to the community, and they have access to different types of information. Generally speaking, their operations are considered low-cost.

Note: 1 = Ministry level; 2 = Province/City level; 3 = District level 


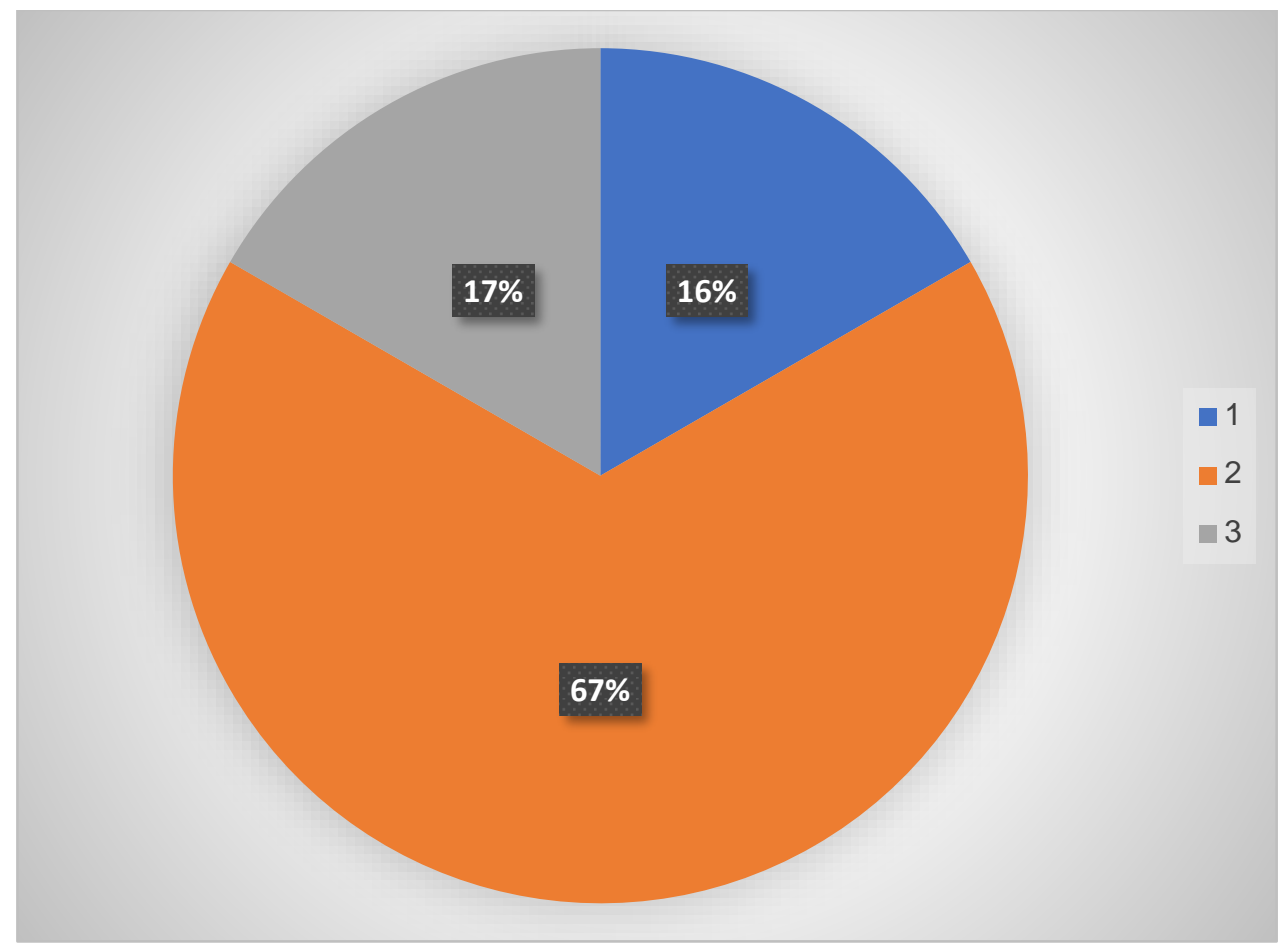

(a) Levels of government agency in protecting environment events

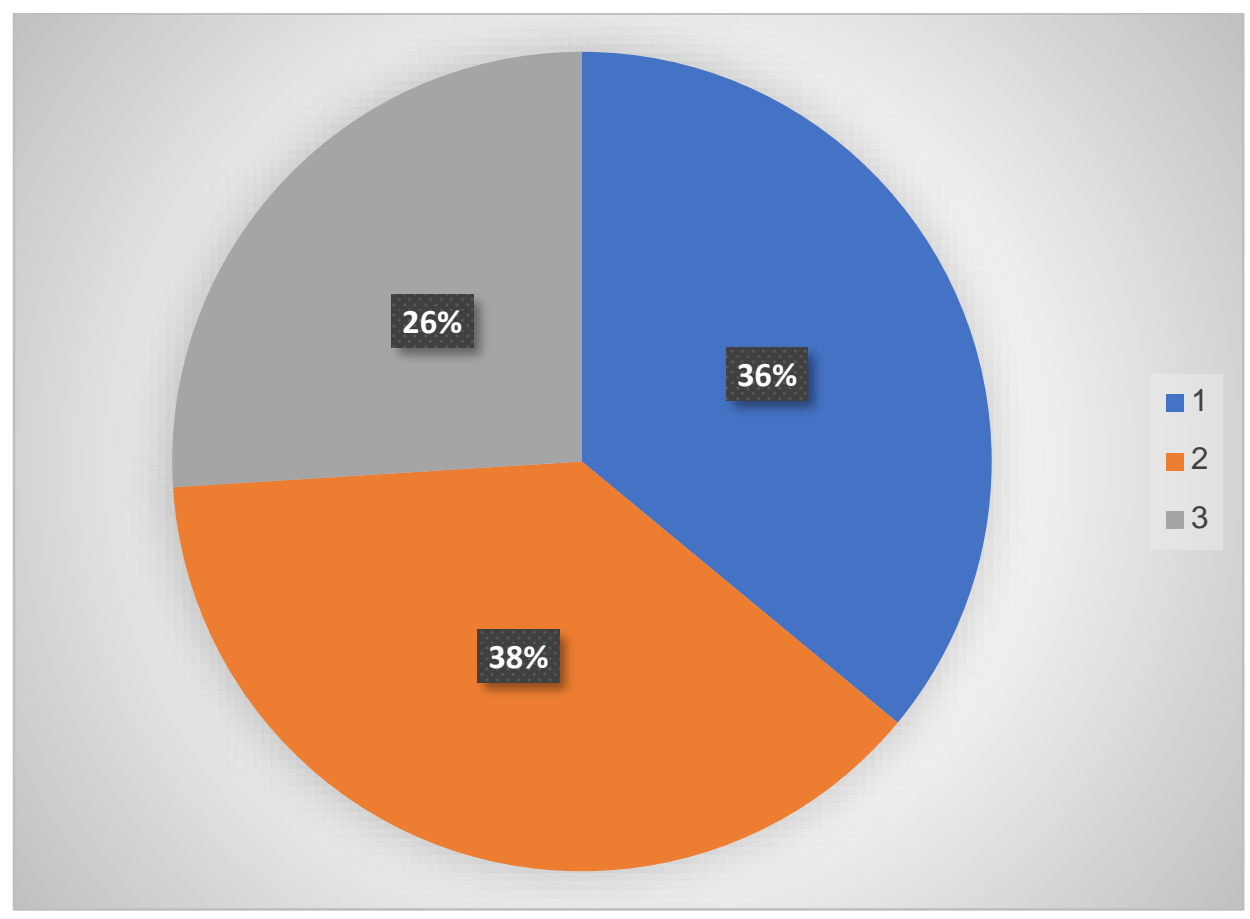

(b) Levels of a government agency in damaging environment events

Figure 7. Levels of government agency participating in events focusing on: (a) protecting the environment, and b) damaging the environment. 
Currently, there is no business that is both damaging the environment and participating in proenvironmental initiatives. However, businesses in the environmental industry are both damaging the environment and protecting it. Potential reasons include the lack of data or the bias of news outlets. Further investigations should pay attention to this behavior.

\section{Discussion}

\section{Implications}

Just as scholars in other developing countries have noted, the findings here concerning Vietnam further bring attention to how business remains a development tool rather than a development agent (Idemudia, 2011). In particular, business engagement with environmental initiatives in Vietnam remains weak, with the focus at a small group of businesses in the service and tourism industry only. There are cases of 'pretentious' environmental initiatives, but further investigation is needed to understand the efforts of other businesses. From a business perspective, pro-environment practices, green productions, and many other 'green' labels are mostly exploited by firms as a useful marketing tool. This result highlights the domination of practical considerations among businesses in Vietnam.

In our data, heavy-industry businesses in Vietnam are still exhibiting neglect toward environmental issues. Numerous cases of environmental destruction involving businesses in heavy industry (i.e., manufacturing, logistics, and forestry) were detected by government agencies, newspapers, and citizens. The list of violations grows along with an increase in the breadth of information sources and social networks. This finding confirms the extant literature that manufacturing and heavy-industry companies have yet to bridge the moral and practical dimensions of environmental sustainability (D. B. Hoang \& Do, 2016; Q. A. Nguyen \& Hens, 2015). It is especially worth noting that a minimum of one governmental agency was involved in $86 \%$ of the events categorized as environmentally damaging. This finding hints at a systemic problem of government-business collusion in bypassing environmental guidelines.

On a grander scale, the lack of transparency in environment-related projects, programs, and initiatives should also be noted. This study has to pool news reports from news outlets and official government portals since there is no database dedicated to the environment or business engagement in environmental practices. The Police Department for Environment does not have a dedicated website that provides information about their activities to the public. Ministry of Natural Resources and Environment or Environment and Natural Resources Departments of respective provinces or cities mostly release information as news reports, which lack a systematic structure to track the information about a particular case or a particular initiative. On the other hand, even though the scattered news reports are the most viable sources of information, they often lack the required details, take time to filter, and potentially be biased.

In order to strengthen the business-society linkage, it is essential to understand business' drivers for engaging in socio-environmental sustainability. What this study suggests in the context of a developing country is the need for systematic information collection and public disclosure on businesses and their engagement in environmental issues. This database can track the actions that a business takes against the environment or the level of dedication of business in protecting the environment. Records of violations, initiatives are tracked and stored in real-time. Furthermore, this database will be of great use for taking future actions in educating, rewarding, or punishing businesses. The database could serve as the basis for developing a community-driven concept for such initiative, business funding, or even crowdfunding is relevant without facing the risk of greenwashing, and the system can be operated on a sustainable basis.

Based on the records in the database, a scoring system to rate the level of environmental friendliness of businesses can be created. This scoring system can be used as a quick tool to raise public 
awareness about businesses. Moreover, the public can also rate the score of a business based on their own experiences with its service and environmental behaviors. Each year, an environmental peer-review award for businesses based on the database and public opinions can be organized into the system for analysis. The database can contribute a methodological and informational system for rating business, while public and expert opinions are curated for the clarification of the data.

Besides rewarding, a system of alarming and punishing anti-environmental behaviors is a needed assessment to tackle the neglect of Vietnamese businesses. Research studies have suggested the benefit of green marketing as an effective branding method (T. N. Nguyen, Lobo, \& Greenland, 2017; T. T. V. Nguyen \& Nguyen, 2016) and as suggested by the findings, there are cases of 'cosmetic' environmental campaigns. Thus, there are reasons for us to believe that there have been even more 'cosmetic' campaigns out there. Therefore, a Red Alert system for business and environmental initiatives should be implemented to identify pretentious, green-washing behaviors. These behaviors should also be punished severely. For instance, the owner or the individual, who causes severe environmental damages, can be put into a blacklist, which prevents them, or even their families, to settle in developed countries. There are cases in Vietnam that have witnessed the effect of severe punishment to companies that destroy nature.

In 2014, international and Cambodian organizations filed a complaint to the Office of the Compliance Advisor Ombudsman, International Finance Corporation, about Hoang Anh Gia Lai (HAGL) for taking away their lands and destroying their forests (IDI, 2020). The incident was followed by international news outlets such as The Guardian, Voice of America, or The Cambodia Daily (Hodal \& Kelly, 2013; Khemara, 2014; Peter \& Pheap, 2015). Even though in Vietnam, there is no information regarding this issue, but the company had been struggling to deal with this issue since. In 2019, after another company bought a large part of the ownership of HAGL's agricultural subsidies, the indigenous people in Cambodia have won back their sacred land (IDI, 2019). Another example is A Cuong Mineral Group (ACM), headquartered in Bac Giang Province, who illegally leaked their unfiltered wastewater into nature in 2015 (Linh, 2015). Consequently, the company's operation has been stopped to fix the problem. The incident has led to financial losses over the past two years (this is a public firm listed on the Hanoi Stock Exchange), and as of September 2019, the company has delayed the payout of its promised dividend of 2015Q1 for the 7th time (Mai, 2019).

In fact, the benefits of damaging the environment would undoubtedly far outweigh the benefits of protecting the environment because the cost is cheaper. Think about the premium price a coffee grower and processor earns from their going-green strategy and that of a real estate business, which profiteers from forests in the name of sustainable development. As more companies are shifting their production to rural areas, there will be a severe problem with resource management and tools for environmental protection data. The resource curse problem appears to have spread to more business sectors in Vietnam than previously thought of (Q. H. Vuong \& Nancy, 2014). Thus, when the 'carrot' shows little use, the 'stick' has to be used to control the lies and violence, which are by no means a new thing in Vietnamese culture (Q. H. Vuong et al., 2020), that are destroying the environment.

The fact is that the environment has become a buzzword. The general public is overexposed to not only the term but also the lineup of environmental issues and solutions: climate change, global warming, ocean acidification, recycle, reuse, reduction, sustainability, etc. The amount of discussion spent on environmental issues, especially climate change, has saturated public attention and trivializes the matter, especially to people who didn't truly feel concerned in the first place. As such, a large part of the public has come to believe that just discussing environmental issues - rather than doing anything about it - is enough. Most measures against environmental issues are conceived to be long-term. Yet, the issue is often brought to attention with short-term urgency (Anderson et al., 2018) and negligence toward the complexity shown in other cases (Q.-H. Vuong, Ho, Nguyen, \& Nguyen, 2019), that makes the issue appear irresoluble and renders the cost of science a whole lot higher (Q.-H. Vuong, 2018). The 
mismatched scale of problems and solutions reduces trust in proposed science-based measures, and proenvironmental initiatives or even lead to defeatist attitudes, all of which threatens the fight against climate change, and the effort to cure the Earth.

\section{Limitations and future directions}

The study is not without its limitations. First, the collection of data is narrowed not just in the country-specific context but also to particular sources-the major news portal on environmental protection and natural resources in Vietnam. The sample could be enlarged to cover more news outlets, which might allow a more analytical categorization of news items. At the same time, it is worth noting that all news outlets in Vietnam are controlled by the state, and thus, news reporting may end up overlapping each other more often than distinguishing from one another. Given that there tends to be consensus on official media in the coverage of environmental protection and destruction, enlarging the news sources could enrich the dataset but would not necessarily change much of the findings. Second, the dataset is expected to grow over time, considering that businesses are constantly developing and finding ways to engage with society and/or the environment. A growing dataset presents new opportunities for more in-depth comparative research on trends of sustainability pursuit by businesses in Vietnam.

\section{Conclusion}

Corporate sustainability is an age-old research topic, and yet, it remains understudied in Vietnam. This is reflected both in the fledging literature as well as the actual business activities in sustainabilityrelated initiatives. Research on corporate sustainability in Vietnam has skewed toward the narrower topic of "corporate social responsibility" or CSR - which has now become a catch-all term with no clear actions. The findings in this study reaffirm the lack of business engagement in environmental sustainability in the manufacturing and heavy industries, a phenomenon that is also seen in other developing countries. At the same time, the news data also suggest that environmental communication is essential in raising awareness of the public and thus, increasing the business-society linkage on sustainability.

If a more comprehensive database on business engagement in sustainability initiatives can be built, it would increase transparency and create room for public scrutiny. Such a move should not be unique to Vietnam but should also be considered in other countries where environmental sustainability has not been taken seriously. Along with the public database, a site dedicated to communicating environmental issues, including reports of relevant enterprises and their incidents, long-form writings about the environment, promotions of environmental initiatives, could greatly benefit the public.

\section{References}

Amaeshi, K., Adi, B. C., Ogbechie, C., \& Amao, O. O. (2006). Corporate Social Responsibility in Nigeria: Western Mimicry or Indigenous Influences? Available at SSRN: https://ssrn.com/abstract=896500 or http://dx.doi.org/10.2139/ssrn.896500.

Anderson, S. E., Bart, R. R., Kennedy, M. C., MacDonald, A. J., Moritz, M. A., Plantinga, A. J., . . . Wibbenmeyer, M. (2018). The dangers of disaster-driven responses to climate change. Nature Climate Change, 8(8), 651-653. doi:10.1038/s41558-018-0208-8

Anh, H. Q., Tomioka, K., Tue, N. M., Suzuki, G., Minh, T. B., Viet, P. H., \& Takahashi, S. (2019). Comprehensive analysis of 942 organic micro-pollutants in settled dusts from northern Vietnam: pollution status and implications for human exposure. Journal of Material Cycles and Waste Management, 21(1), 57-66. doi:10.1007/s10163-018-0745-2 
Arevalo Jorge, A., \& Aravind, D. (2011). Corporate social responsibility practices in India: approach, drivers, and barriers. Corporate Governance: The international journal of business in society, 11(4), 399-414. doi:10.1108/14720701111159244

Bansal, P., \& Bogner, W. C. (2002). Deciding on ISO 14001: Economics, Institutions, and Context. Long Range Planning, 35(3), 269-290. doi:https://doi.org/10.1016/S0024-6301(02)00046-8

Bansal, P., \& Roth, K. (2000). Why Companies Go Green: A Model of Ecological Responsiveness. Academy of Management Journal, 43(4), 717-736. doi:10.5465/1556363

Brønn, P. S., \& Vidaver-Cohen, D. (2009). Corporate Motives for Social Initiative: Legitimacy, Sustainability, or the Bottom Line? Journal of Business Ethics, 87(1), 91-109. doi:10.1007/s10551-008-9795-Z

Carroll, A. B., \& Shabana, K. M. (2010). The Business Case for Corporate Social Responsibility: A Review of Concepts, Research and Practice. International Journal of Management Reviews, 12(1), 85-105. doi:10.1111/j.1468-2370.2009.00275.x

Davis, K. (1973). The case for and against business assumption of social responsibilities. Academy of Management Journal, 16(2), 312-322.

De Bakker, F. G. A., Groenewegen, P., \& Den Hond, F. (2005). A Bibliometric Analysis of 30 Years of Research and Theory on Corporate Social Responsibility and Corporate Social Performance. Business \& Society, 44(3), 283-317. doi:10.1177/0007650305278086

Do, H. K., \& Tran, V. A. (2017). Impact of stakeholders on the performance of green banking products and services: The case of Vietnamese banks. Economic Annals-XXI, 165(5-6), 143-151. doi:10.21003/ea.v165-29

Donaldson, T. (1982). Corporations and Morality. Englewood Cliffs, NJ: Prentice-Hall.

Elkington, J. (1994). Towards the Sustainable Corporation: Win-Win-Win Business Strategies for Sustainable Development. California Management Review, 36(2), 90-100. doi:10.2307/41165746

FAO. (2001). Global Forest Resources Assessment 2000. Retrieved from Rome:

Folmer, H., \& Tietenberg, T. H. (Eds.). (2005). The International Yearbook of Environmental and Resource Economics 2005/2006: A Survey of Current Issues. Cheltenham, United Kingdom: Edward Elgar.

Gray, R. (2010). Is accounting for sustainability actually accounting for sustainability....and how would we know? An exploration of narratives of organisations and the planet. Accounting, Organizations and Society, 35(1), 47-62. doi:https://doi.org/10.1016/j.aos.2009.04.006

Gugler, P., \& Shi, J. Y. J. (2009). Corporate Social Responsibility for Developing Country Multinational Corporations: Lost War in Pertaining Global Competitiveness? Journal of Business Ethics, 87(1), 3-24. doi:10.1007/s10551-008-9801-5

Ha, D. (2019). Nhà vệ sinh của khách sạn, công ty thành nhà vệ sinh miễn phí [Hotels, companies' restrooms turned into public restrooms]. Retrieved from https://tuoitre.vn/nha-ve-sinh-cuakhach-san-cong-ty-thanh-nha-ve-sinh-mien-phi-20190423163917645.htm

Hahn, T., Figge, F., Pinkse, J., \& Preuss, L. (2010). Trade-offs in corporate sustainability: you can't have your cake and eat it. Business Strategy and the Environment, 19(4), 217-229. doi:10.1002/bse.674

Hahn, T., \& Scheermesser, M. (2006). Approaches to corporate sustainability among German companies. Corporate Social Responsibility and Environmental Management, 13(3), 150-165. doi:10.1002/csr.100

Hamm, B. (2012). Corporate social responsibility in Vietnam. Pacific News, 38(July/August 2012), 4-8.

Hammann, E.-M., Habisch, A., \& Pechlaner, H. (2009). Values that create value: socially responsible business practices in SMEs - empirical evidence from German companies. Business Ethics: A European Review, 18(1), 37-51. doi:10.1111/j.1467-8608.2009.01547.x

Hedberg, C.-J., \& von Malmborg, F. (2003). The Global Reporting Initiative and corporate sustainability reporting in Swedish companies. Corporate Social Responsibility and Environmental Management, 10(3), 153-164. doi:10.1002/csr.38

Hemingway, C. A. (2005). Personal Values as A Catalyst for Corporate Social Entrepreneurship. Journal of Business Ethics, 60(3), 233-249. doi:10.1007/s10551-005-0132-5 
Hoang, D. B., \& Do, B. K. (2016). Business responses to climate change: strategies for reducing greenhouse gas emissions in Vietnam. Asia Pacific Business Review, 23(4), 596-620. doi:10.1080/13602381.2016.1212557

Hoang, T. C., Black, M. C., Knuteson, S. L., \& Roberts, A. P. (2019). Environmental Pollution, Management, and Sustainable Development: Strategies for Vietnam and Other Developing Countries. Environmental Management, 63(4), 433-436. doi:10.1007/s00267-019-01144-z

Hodal, K., \& Kelly, C. (2013). Deutsche Bank and IFC accused of bankrolling Vietnam firms' land grabs. Retrieved from https://www.theguardian.com/world/2013/may/13/deutsche-bank-ifc-bankrollvietnam-cambodia-laos

Idemudia, U. (2011). Corporate social responsibility and developing countries: moving the critical CSR research agenda in Africa forward. Progress in Development Studies, 11(1), 1-18. doi:10.1177/146499341001100101

IDI. (2019). Cambodian indigenous communities win back their sacred land from Vietnamese rubber developer. Retrieved from https://www.inclusivedevelopment.net/cambodian-indigenouscommunities-win-back-their-sacred-land-from-vietnamese-rubber-developer/

IDI. (2020). Cambodia: Hoang Anh Gia Lai rubber plantations. Retrieved from https://www.inclusivedevelopment.net/campaign/cambodia-rubber-land-grabs/

Jamali, D. (2014). CSR in developing countries through an institutional lens. Corporate social responsibility and sustainability: Emerging trends in developing economies, 8, 21-44.

Khan, F. R., \& Lund-Thomsen, P. (2011). CSR As Imperialism: Towards a Phenomenological Approach to CSR In the Developing World. Journal of Change Management, 11(1), 73-90. doi:10.1080/14697017.2011.548943

Khanal, B. R., \& Babar, J. T. (2007). Community based ecotourism for sustainable tourism development in the Mekong region. Policy Brief, 1, 2007.

Khemara, S. (2014). Rubber Company Suspends Projects as World Bank Investigates. Retrieved from https://www.voacambodia.com/a/rubber-company-suspends-projects-as-world-bankinvestigates/1908775.html

Khoi, N. V., Dung, V. A., \& Nga, N. Q. (2016). R\&D Investment of Japanese Multinational Corporations in Vietnam through Green Supply Chain: The Case of Ajinomoto. Journal of Sustainability Science and Management, 11(1), 43-52.

Le, Y., Hollenhorst, S. J., \& Triplett, J. (2005). Business Perspectives of Adopting Sustainable Tourism Practices: A Study of Tourism Companies in Vietnam. Téoros, 24(2), 56-68.

Leisinger, K. (2015). Business needs to embrace sustainability targets. Nature Column: World View, 528(165). Retrieved from doi:10.1038/528165a

Lin, R.-J., Tan, K.-H., \& Geng, Y. (2013). Market demand, green product innovation, and firm performance: evidence from Vietnam motorcycle industry. Journal of Cleaner Production, 40, 101-107. doi:10.1016/j.jclepro.2012.01.001

Linh, G. (2015). Công ty Á Cường bị đình chỉ sản xuất và yêu cầu khắc phục ô nhiễm môi trường [A Cuong Mineral Group was prohibited from mining and needed to solve the environmental pollution]. Retrieved from http://tapchimoitruong.vn/pages/article.aspx?item=C\%C3\%B4ng-ty$\% \mathrm{C} 3 \% 81-\mathrm{C} \% \mathrm{C} 6 \% \mathrm{~B} 0 \% \mathrm{E} 1 \% \mathrm{BB} \% 9 \mathrm{Dng}-\mathrm{b} \% \mathrm{E} 1 \% \mathrm{BB} \% 8 \mathrm{~B}-\% \mathrm{C} 4 \% 91 \% \mathrm{C} 3 \% \mathrm{ACnh}-$ ch\%E1\%BB\%89-s\%E1\%BA\%A3n-xu\%E1\%BA\%A5t-v\%C3\%A0-y\%C3\%AAuc\%E1\%BA\%A7u-kh\%E1\%BA\%AFc-ph\%E1\%BB\%A5c-\%C3\%B4-nhi\%E1\%BB\%85mm\%C3\%B4i-tr\%C6\%B0\%E1\%BB\%9Dng-41468

Liu, Z. (2003). Sustainable Tourism Development: A Critique. Journal of Sustainable Tourism, 11(6), 459-475. doi:10.1080/09669580308667216

Luu, T. T. (2018). Employees' green recovery performance: the roles of green HR practices and serving culture. Journal of Sustainable Tourism, 26(8), 1308-1324. doi:10.1080/09669582.2018.1443113

Mai, T. (2019). Khoáng sản Á Cường (ACM) lại "khất" trả cổ tức lần thứ 7 [A Cuong Mineral Group has delayed paying the dividend for the 7th time]. Retrieved from https://cafef.vn/khoang-san-acuong-acm-lai-khat-tra-co-tuc-lan-thu-7-20190626112921593.chn 
Mai, T., \& Smith, C. (2015). Addressing the threats to tourism sustainability using systems thinking: a case study of Cat Ba Island, Vietnam. Journal of Sustainable Tourism, 23(10), 1504-1528. doi:10.1080/09669582.2015.1045514

Marsden, C. (2000). The New Corporate Citizenship of Big Business: Part of the Solution to Sustainability? Business and Society Review, 105(1), 8-25. doi:10.1111/0045-3609.00062

McElwee, P. (2016). Forests are Gold: Trees, People, and Environmental Rule in Vietnam. Seattle: University of Washington Press.

Meyfroidt, P., \& Lambin, E. F. (2008). Forest transition in Vietnam and its environmental impacts. Global Change Biology, 14(6), 1319-1336. doi:10.1111/j.1365-2486.2008.01575.x

Milne, M. J., \& Gray, R. (2013). W(h)ither Ecology? The Triple Bottom Line, the Global Reporting Initiative, and Corporate Sustainability Reporting. Journal of Business Ethics, 118(1), 13-29. doi:10.1007/s10551-012-1543-8

Moore, S., \& Jie Wen, J. (2008). Business ethics? A global comparative study on corporate sustainability approaches. Social Responsibility Journal, 4(1/2), 172-184. doi:10.1108/17471110810856938

Moratis, L. (2016). Out of the ordinary? Appraising ISO 26000's CSR definition. International Journal of Law and Management, 58(1), 26-47.

Morris, M. H., Schindehutte, M., Walton, J., \& Allen, J. (2002). The Ethical Context of Entrepreneurship: Proposing and Testing a Developmental Framework. Journal of Business Ethics, 40(4), 331-361. doi:10.1023/A:1020822329030

Nam, V. T. (2016, 2016). Environmental Pollution-The Barrier to Sustainable Development on Breeding Industrial Chicken in Southeast Provinces of Vietnam. Paper presented at the 2016 3rd International Conference on Green Technology and Sustainable Development (GTSD), Kaohsiung, Taiwan.

Nguyen, G. N. T., \& Sarker, T. (2018). Sustainable coffee supply chain management: a case study in Buon Me Thuot City, Daklak, Vietnam. International Journal of Corporate Social Responsibility, 3(1). doi:10.1186/s40991-017-0024-x

Nguyen, H. P., \& Pham, H. T. (2011). The Dark Side of Development in Vietnam. Journal of Macromarketing, 32(1), 74-86. doi:10.1177/0276146711423666

Nguyen, H. T., \& Gray, M. (2016). A Review on Green Building in Vietnam. Procedia Engineering, 142, 314-321. doi:10.1016/j.proeng.2016.02.053

Nguyen, M., \& Truong, M. (2016). The Effect of Culture on Enterprise's Perception of Corporate Social Responsibility: The Case of Vietnam. Procedia CIRP, 40, 680-686. doi:https://doi.org/10.1016/j.procir.2016.01.154

Nguyen, Q. A., \& Hens, L. (2015). Environmental performance of the cement industry in Vietnam: the influence of ISO 14001 certification. Journal of Cleaner Production, 96, 362-378. doi:https://doi.org/10.1016/j.jclepro.2013.09.032

Nguyen, T. N., Lobo, A., \& Greenland, S. (2017). Energy efficient household appliances in emerging markets: the influence of consumers' values and knowledge on their attitudes and purchase behaviour. International Journal of Consumer Studies, 41(2), 167-177. doi:10.1111/ijcs.12323

Nguyen, T. T. V., \& Nguyen, T. D. (2016, 24-25 Nov. 2016). Green Marketing Strategy - A New Trend for Businesses in Vietnam. Paper presented at the 2016 3rd International Conference on Green Technology and Sustainable Development (GTSD).

Nguyen, T. T. H., Yang, Z., Nguyen, N., Johnson, L. W., \& Cao, T. K. (2019). Greenwash and Green Purchase Intention: The Mediating Role of Green Skepticism. Sustainability, 11(9), 2653. doi:10.3390/su11092653

Panapanaan, V. M., Linnanen, L., Karvonen, M.-M., \& Phan, V. T. (2003). Roadmapping Corporate Social Responsibility in Finnish Companies. Journal of Business Ethics, 44(2), 133-148. doi:10.1023/A:1023391530903

Peter, Z., \& Pheap, A. (2015). R'kiri Families Reach 'Major Breakthrough' With Firm. Retrieved from https://english.cambodiadaily.com/news/rkiri-families-reach-major-breakthrough-with-firm94849/ 
Schaltegger, S., \& Burritt, R. (2018). Business Cases and Corporate Engagement with Sustainability: Differentiating Ethical Motivations. Journal of Business Ethics, 147(2), 241-259. doi:10.1007/s10551-015-2938-0

Schaltegger, S., \& Synnestvedt, T. (2002). The link between 'green' and economic success: environmental management as the crucial trigger between environmental and economic performance. Journal of Environmental Management, 65(4), 339-346. doi:https://doi.org/10.1006/jema.2002.0555

Stucki, Flammini, Beers, Phuong, Anh, Dong, . . . Hieu. (2019). Eco-Industrial Park (EIP) Development in Viet Nam: Results and Key Insights from UNIDO's EIP Project (2014-2019). Sustainability, 11(17), 4667. doi:10.3390/su11174667

Tencati, A., Russo, A., \& Quaglia, V. (2010). Sustainability along the global supply chain: the case of Vietnam. Social Responsibility Journal, 6(1), 91-107. doi:10.1108/17471111011024577

Tseng, M.-L., Wu, K.-J., Lee, C.-H., Lim, M. K., Bui, T.-D., \& Chen, C.-C. (2018). Assessing sustainable tourism in Vietnam: A hierarchical structure approach. Journal of Cleaner Production, 195, 406417. doi:https://doi.org/10.1016/j.jclepro.2018.05.198

Tu, T. T. T., \& Yen, T. T. H. (2015). Green bank: International experiences and Vietnam perspectives. Asian Social Science, 11(28), 188.

United Nations. (1992). The Rio Declaration on Environment and Development. Retrieved from https://www.un.org/en/development/desa/population/migration/generalassembly/docs/globalcomp act/A CONF.151 26 Vol.I Declaration.pdf

United Nations. (2020). The Sustainable Development Agenda. Retrieved from https://www.un.org/sustainabledevelopment/development-agenda/

Vallaster, C., Kraus, S., Merigó Lindahl, J. M., \& Nielsen, A. (2019). Ethics and entrepreneurship: A bibliometric study and literature review. Journal of Business Research, 99, 226-237. doi:https://doi.org/10.1016/j.jbusres.2019.02.050

van Marrewijk, M. (2003). Concepts and Definitions of CSR and Corporate Sustainability: Between Agency and Communion. Journal of Business Ethics, 44(2), 95-105. doi:10.1023/A:1023331212247

Visser, W. (2008). Corporate social responsibility in developing countries. In D. M. Andrew Crane, Abagail McWilliams, Jeremy Moon, and Donald S. Siegel (Ed.), The Oxford Handbook of Corporate Social Responsibility. Oxford, UK: Oxford University Press.

Vuong, Q.-H. (2018). The (ir)rational consideration of the cost of science in transition economies. Nature Human Behaviour, 2(1), 5-5. doi:10.1038/s41562-017-0281-4

Vuong, Q.-H., Ho, M.-T., Nguyen, H.-K. T., \& Nguyen, M.-H. (2019). The trilemma of sustainable industrial growth: evidence from a piloting OECD's Green city. Palgrave Communications, 5(1), 156. doi:10.1057/s41599-019-0369-8

Vuong, Q. H. (2015). Be rich or don't be sick: estimating Vietnamese patients' risk of falling into destitution. SpringerPlus, 4(1), 529. doi:10.1186/s40064-015-1279-x

Vuong, Q. H., \& Nancy, K. N. (2014). Resource curse or destructive creation in transition: Evidence from Vietnam's corporate sector. Management Research Review, 37(7), 642-657. doi:10.1108/MRR12-2012-0265

Vuong, Q. H., Nguyen, T. H. K., Ho, M. T., La, V. P., Vuong, T. T., Tran, T., . . Ho, M. T. (2020). On how religions could accidentally incite lies and violence: Folktales as a cultural transmitter. Palgrave Communications, 6, Accepted/Article in Press.

Wagner, M. (2010). The role of corporate sustainability performance for economic performance: A firmlevel analysis of moderation effects. Ecological Economics, 69(7), 1553-1560. doi:https://doi.org/10.1016/j.ecolecon.2010.02.017

World Bank. (2020). The World Bank in Vietnam - Overview. Retrieved from https://www.worldbank.org/en/country/vietnam/overview

World Commission on Environment and Development. (1987). From One Earth to One World: An Overview. Oxford: Oxford University Press. 
Zadek, S. (2001). Third generation corporate citizenship: public policy and business in society. A Foreign Policy Centre/Accountability Report. Retrieved https://www.files.ethz.ch/isn/20949/Third_Generation_Corporate_Citizenship.pdf

Zhu, Q., \& Zhang, Q. (2015). Evaluating practices and drivers of corporate social responsibility: the Chinese context. Journal of Cleaner Production, 100, 315-324. doi:https://doi.org/10.1016/j.jclepro.2015.03.053 